\title{
Determinants of smallholder households' resilience to livelihood insecurity in Goncha district, Northwest highlands of Ethiopia
}

\author{
${ }^{1}$ Ermias Debie \& ${ }^{2}$ Amare Wubishet Ayele \\ ${ }^{1}$ Department of Geography and Environmental Studies, Bahir Dar University, Bahir Dar, Ethiopia \\ Email: ermi272004@gmail.com \\ Personal phone numbers: +251912990376 \\ ${ }^{2}$ Departments of Statistics, Debre Markos University, Debre Markos, Ethiopia \\ Personal phone numbers: +251912849005 \\ Email: amarewubishet21@gmail.com
}

Corresponding author: Ermias Debie (Email: ermi272004@gmail.com)

\begin{abstract}
Poor households are more likely less resilient under climate change, risks of productive assets, social-related shocks, and decline of land productivity. The ability to deal with household resilience against poverty under the uncertain condition of risk is limited in the highlands of Ethiopia. The study aims to identify determinants of household resilience to livelihood insecurity under the crop-livestock mixed farming systems in Goncha district, Northwest highlands of Ethiopia. Primary data were collected by conducting face-to-face interviews among 280 households using structured questionnaire. Descriptive statistics, Kruskal-Wallis test and structural equation modeling were used to analyse the data. The results disclosed that sustainable management of the farming systems, cultivation of more fertile farmland, saving performance, diversification of income-earning activities, intensification of livestock husbandry practices, access to irrigation, and familiarity with practical technologies were found to be significant determinants at $\mathrm{p}<0.001$ to household resilience of smallholder farmers. Social network development and tree plantation were explained household resilience to livelihood insecurity at $\mathrm{P}<0.01$ and $\mathrm{P}<0.1$ significant levels, respectively. The study concluded that scaling up sustainable management of the farming system and practical technologies, enhancing saving behavior, promoting income diversification, and intensifying agroforestry are significant for household resilience to livelihood insecurity of smallholders across agro-ecologies.
\end{abstract}

Keywords: Mixed farming; Household resilience; livelihood insecurity; Diversification; structural equation model

\section{Introduction}

Over the past fifty years anthropogenic activities changed world ecosystems more extensively and accelerating land degradation than at any other time in history [80]. Land degradation is one of the biggest contributors to climate change attributable to emission of soil carbon and nitrous oxide into atmosphere. It contributes to reduce the effectiveness of adaptation options and increase the vulnerability of agroecological systems to climate change [97]. Land degradation threatens the livelihood of millions of subsistence farmers in developing countries [89]. This situation is more prevalent in Sub-Saharan Africa (SSA) where rapid growing human populations are mainly dependent on natural resources (soil, water and vegetation) and confronted by rain-fed agriculture [77]. Rain-fed agricultural activities are confronted with yield, market, institutional, assets and financial risks livelihoods [25]. In Sub-Saharan Africa, livelihoods vulnerability of smallholder households remains at high level due to innovative investments not targeted on the adaptation of land degradation and climate variability induced uncertain production [29]. Severe soil degradation and declined land productivity impact negatively on the local communities' foods security and resilience to climate variability in many parts of Eastern Africa [53, 58].

Natural resources-based livelihoods through the crop-livestock mixed farming system are highly susceptible to the effects of common disturbance shocks and risks, such as land degradation, climate variability, and drought $[86,25,76,43,81]$. The accelerated rate of land degradation seriously affects soil productivity, threatens livelihood options and food security of subsistence farmers, and worsens poverty in Ethiopia's highlands [54]. Moreover, institutional risks due to weak policies and regulations affect farmers' adaptive capacity and resilience through increasing vulnerability $[25,43]$. To remedy this, efforts need to be made to improve land productivity through relevant agro-ecological-based management programs that could go a long way in the sustainable use of natural resources with household resilience for livelihood security.

Household resilience is the ability to deal with shocks, improve adaptive capacity, and secure sufficient food [9, $27,87,21]$. It is the capacity to prevent households from falling below the acceptable level of food security, poverty, and wellbeing despite high competence under the uncertain condition of risk [29, 9, 17, 28, 87]. 
Building household resilience requires an integrated approach. Household resilience against poverty and food insecurity depends on the interface between risks, assets, and socio-institutional context [87]. It is characterized as greater income and asset development through diverse sources with innovative self-organization mechanisms $[27,87,96]$. Integrating management of land and water resources, developing a more varied asset base, engaging in farm diversification, practicing risk-tolerant varieties, augmenting people's adaptive capacity, and participation in formal and informal social safety nets are major strategies that contribute to household resilience $[27,95]$. Improved human capital, participation in diverse social networks, access to information, and openness to sustainable agriculture, value-added practices, and technological innovation are also principal factors for achieving resilience at the household level [43]. Across diverse livelihood zones of Ethiopia, numerous studies conducted on livelihood vulnerability to climate change induced hazards [34, 2, 11, 61, 65] and household resilience to food insecurity $[92,56,1]$. Household resilience to food insecurity implies that the ability of household to maintain a certain level of food security when faced with agricultural drought and other shocks [71]. It can be determined by institutional, social, economic, and natural enabling conditions [80, 20].

Food security is one major subset of livelihood security. Livelihood security is the ability of a household to have adequate and sustainable access to income and resources to meet basic needs, including adequate food, health, shelter, income, basic education, personal safety and community participation [45]. Livelihood insecurity is the contributing cause to poverty [36]. Poor farm households are more vulnerable to livelihood insecurity under climate change, the risks of productive assets, social-related shocks, and the decline of land productivity in northwest highlands of Ethiopia. The ability to deal with household resilience levels against poverty under the uncertain condition of risks is limited in the highlands of Ethiopia. Therefore, this study aims to determine factors affecting household resilience to livelihood insecurity under the crop-livestock mixed farming systems in Goncha district, Northwest highlands of Ethiopia.

\section{Materials and Methods}

\subsection{Location}

This study was conducted in the Goncha district of Amhara Region, Northwest Ethiopia. The district lies between $10^{\circ} 46^{\prime} 14.45^{\prime \prime} \mathrm{N} \_11^{\circ} 9^{\prime} 30.37^{\prime \prime} \mathrm{N}$ latitude and 380'11.669"E_38 23'43.514"E longitude (Figure 1).

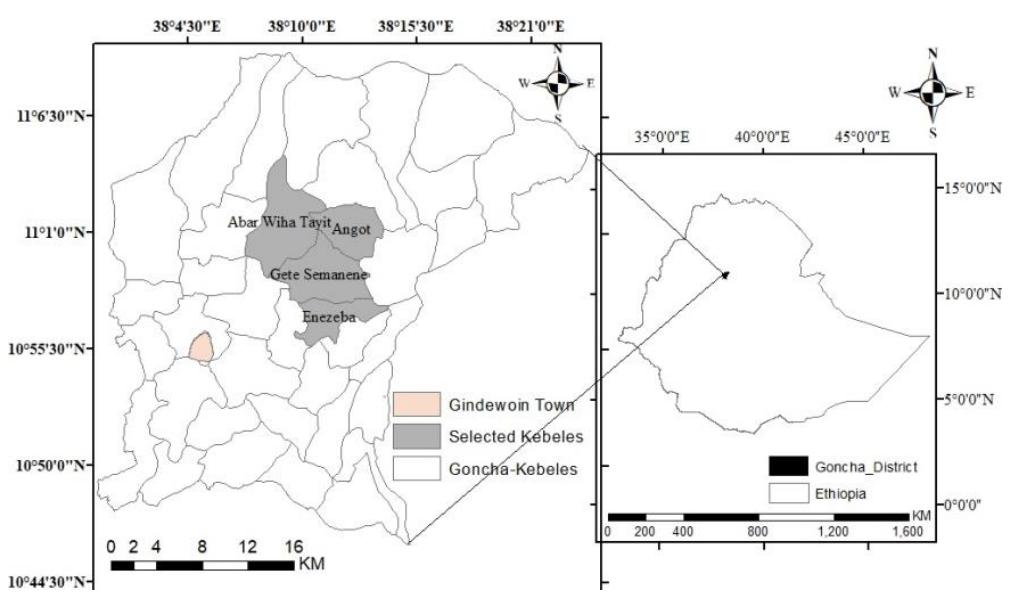

Figure 1. Map of the study area

\subsection{Farming system}

The study district is characterized by diverse topography with major landforms. The landforms include gently sloping to slightly dissected plain and rugged plateau. The climatic condition is largely characterized by subhumid type. Three agro-ecological zones, such as cool-moist highlands, tepid-moist mid-highland, and warmmoist lowland, are equivalent to the Ethiopian traditional agro-ecological zones of dega, woina-dega, and kola, respectively are evident. Primitive and subsistence agriculture under crop-livestock mixed farming systems are the predominant livelihood system in all the agro-ecological zones, found with elevation ranges 1295 to 3488 masl. Lands and livestock are the most important natural assets to the community. Communal resources, such as forests, shrublands, wetlands, and grasslands are usually managed by the local community and administration unit. The hilly and steep slope communal lands of the watershed are highly threatened by vegetation degradation and dissected by gullies due to uncontrolled overgrazing and deforestation with weak institutional arrangements. Cropland and settlement units are the largest land-use systems that are privately owned and managed by a farmer. Conventional tilling through a hand press with ox-pulling traditional technique is the most common form of crop productions. In the dega agro-ecological zone (above 2800 meters elevation of cool-moist highlands) barley (Hordeum vulgare) \& potato (Solanum tuberosum) are chiefly produced. Degradation and soil acidity are more serious problems in the hills. In the woina-dega agro-ecological zone, tef (Eragrostis tef), 
barley (Hordeum vulgare), wheat (Triticum Vulgare), and, horse beans (Vicia Faba), and others are grown. Tef (Eragrostis tef), and wheat (Triticum Vulgare) are predominantly grown crops among others. In the kola agroecological zone sorghum is largely produced. Agricultural production is suffering from erratic rains and severe ecological degradation. Local labor and firewood/charcoal/ sales are alternative means of income for farmers to meet their food needs. Cattle, sheep, goat, donkey, and horse are reared under the cut-and-carry and opengrazing systems.

\subsection{Conceptual framework}

A livelihood comprises the capabilities, assets and activities required for a means of living, while not undermining the natural resource base [82]. Livelihood strategies depend upon access and availability to natural, physical, human, financial and social assets. Crop-livestock mixed farming is the principal livelihood strategy of smallholder farmers in the highlands of Ethiopia. It is sensitive to common disturbance shocks and risks, such as drought, climate variability, soil degradation and social related risks [72, 81]. The ability to quickly and effectively respond (adaptive capacity) to changing environmental conditions, such as land degradation, climate variability and drought is core factor in achieving livelihood resilience at household level [43]. Livelihood resilience is characterized by actors' assets and strategies to maintain and increase assets; learn and self-organize [87]. It is the ability of household to avoid poverty overtime [17] or to manage change by maintaining or transforming living standards [37] in the face of shocks or stresses without compromising their long-term prospects. Building livelihood resilience requires an integrated approach and long-term commitment to improve absorptive capacity with persistence outcome, adaptive capacity at incremental adjustment, and escaping chronic poverty through improved governance and enabling conditions [20]. For this study, livelihood resilience is the households' ability to maintain livelihood security in the face climate uncertainty and related shocks and risks without compromising long-term prospects. It is being able to pursue safe and sustainable strategies to secure enough food, health, nutrition, income, education, and shelter without suffering periodic shortage for long-term $[27,87]$.

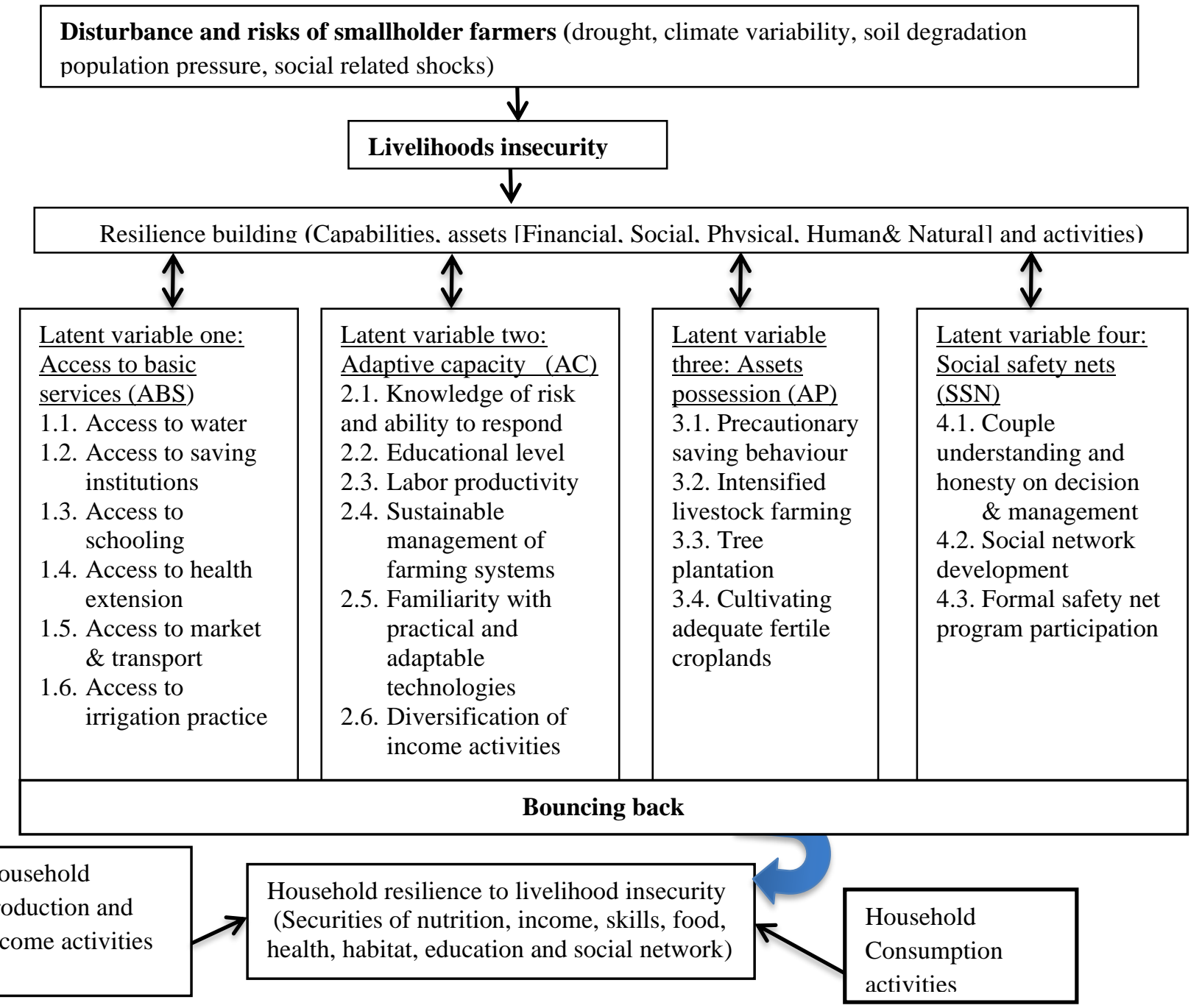

Figure 2. The framework of four latent variables and nineteen observed variables of household resilience 
Adaptive capacity, access to basic services, asset possession, and social safety nets are fundamental factors/variables of household resilience [42]. Based on the literatures, four latent variables of resilience, and nineteen indicators or observed variables were incorporated in the framework through considering the local condition (Figure 2). The framework provides the degree of resilience-building variation from one household to another household. The variation of household resilience to livelihood insecurity can be determined by diverse factors and indicators. The factors include access to basic services, adaptive capacity, assets possession and social safety net. Access to basic services factor contains diverse indicators, including access to water, access to saving institutions, access to schooling, access to health extension, and access to market \& transport, access to irrigation practice. Assets possession and availability is an important coping mechanism during periods of hardship [7]. Assets possession factor comprises precautionary saving behaviour, intensified livestock farming, tree plantation, and cultivated adequate fertile croplands. Adaptive capacity depicts a household's capacity to cope with and adapt to a certain shocks and risks. It is measured incorporating indicators, such as knowledge of risk and ability to respond, educational level, labour productivity, sustainable management of farming systems, familiarity with practical and adaptable technologies, and diversification of income activities. Besides, couple understanding and honesty on decision and management, social network development and formal safety net program participation are indicators to measure social safety net factor.

\subsection{Sampling}

Goncha district was selected purposively as a typical area of crop-livestock mixed farming system under diverse agroecologies, northwest highlands of Ethiopia. Four Kebeles (small administrative units), namely GeteSemanen from woina-dega agroecology, Enezeba from dega agroecology, and Angot and Abarwuha-Tayit from kola agroecology zone were selected randomly. By considering the desired confidence level (1- $\alpha)$, degrees of variability from the mean $\left(\sigma^{2}\right)$, the desired precision $(d)$, and design effect $(D E)$ were considered to determine the sample size from the selected Kebeles. Hence, the sample size (n) was determined by using the formula [85, 26]:

$n=\left(\frac{Z_{\alpha / 2}}{d}\right)^{2} \times \sigma^{2} \times D e f f$

By considering the $90 \%$ confidence interval $(z \alpha / 2=1.64), 5 \%$ margin of error, estimated design effect of 1.105 , and variance of household resilience index of 0.941 from a pilot study, the sample size was determined at 280 household heads. The household heads were identified using a systematic sampling technique from different agroecologies, including woina-dega, dega, and kola. Lists of respondents' clusters were obtained from Kebele development agent (KDA) offices.

\subsection{Data collection method}

A household survey was undertaken using pre-arranged and structured guiding tools. Face-to-face interviews were conducted among all the sampled farmers. The enumerators with close supervision of the researchers were responsible to carry out the interview. In the use of survey weights, the informants assigned the ranks for each indicator according to the perceived relative importance to their household resilience. Ranks were assigned according to the following five Likert scale points, such as $1=$ very low importance, $2=$ low importance, $3=$ moderate importance, $4=$ high importance, and 5= very high importance [88]. Informants assigned the actual scores to each indicator performance in line with the perceived desire condition of household resilience. The scoring was assigned as $1=$ very weak, $2=$ poor, $3=$ acceptable or average, $4=$ very favorable, and 5= outstanding .

\subsection{Methods of analysis}

Weighted score method was used to identify the relative importance of indicator for household resilience to livelihood insecurity. The relative weight of each indicator was calculated by dividing its weight by the total of all weights of the indicators under the latent variable [9].

$$
W i=\frac{w i}{\sum_{i}^{n}=1 w i}
$$

, where: Wi is the relative weight of each indicator, 'wi' is the weight of each indicator, and ' $\Sigma$ wi' is the total of all weights of the indicators under the latent variable.

The performance score of pillar "Pi" can be calculated using the equations of the weighted score method [67; 78]:

$$
p_{i}=\sum_{i=1}^{n} w_{i} x_{i}
$$


, where: under the " $\mathrm{Pi}$ " = is the weighted score of ' $\mathrm{i}$ ' pillar; wi= the relative weight of indicator ' $i$ ' estimated from equation one; $x i=$ actual score of the indicator ' $i$ '.

The principal component analysis (PCA) was conducted to construct the household resilience index (HRI). The household resilience index (HRI) was calculated using the following equation [75].

$$
\mathrm{HRI}=\frac{\sum_{\mathrm{hi}}^{\mathrm{n}}=1 \mathrm{pj}}{\mathrm{n}}
$$

, where 'HRI' is an individual household resilience to livelihood insecurity; ' $\mathrm{Pj}$ ' is the weighted score of ' $j$ ' pillar; ' $n$ ' is the number of pillars or latent variables, and ' $h i$ ' is the individual household.

A structural equation model (SEM) was used to identify factors determining household resilience to livelihood insecurity. It denotes the general relationships among multiple theoretical constructs represented by the latent variables [51, 41]. The model is a powerful technique increasingly used in scientific investigation to test multivariate causal relationships and differs from other modeling as it tests the direct and indirect effects on preassumed causal relationships [41]. It applies a confirmatory factor analysis to measure latent constructs via observed variables. Confirmatory factor analysis could reduce the data dimensions, standardize the scale of multiple indicators and account for the correlations inherent in the dataset. Latent variable is derived common factor of observed variables based on the correlation variations of datasets (association or causal relationship). The model was calculated using the following equation.

$H R I=f(A B S, A C, A P, S S N)$

Where; ABS - access to basic services, AC - implies adaptive capacity; AP-asset possession; and SSN- social safety net.

Kruskal-Wallis $\mathrm{H}$ test was used to test the significant difference of household resilience to livelihood insecurity across agro-ecologies. The overall statistical analysis was done using the Stata version-14 statistical software.

\section{Results and Discussions}

\subsection{Socioeconomic Characteristics of the Respondents}

Table-1 portrays basic description of socioeconomic characteristics of the respondents. The respondents were composed from $81.43 \%$ of male and $18.57 \%$ of female-head households. The male-headed households were more effective in agricultural productivity than female-headed households due to lower capacity of assets accumulation [48]. Female headed households are less resilient than male-headed because of low adaptive capacity, lack of assets and more vulnerability [22, 61]. Farming experience and age are continuous variables considering in the study. The average age of the respondents was 44.27 years. When farmers age increase, their experience in the farming activities is expected to increase. The average farming experience of the household was 25.44 years. Farming experience is one of the important human capitals for livelihood security of rural farm households.

In the study area, family size, productive household size, educational level, agroecology, wealth status, and land ownership status are important factors for the sustainable farming system of the rural household. From the total, $47.14 \%$ of households had read and write education status, while $9.29 \%$ farm household educated at secondary and above grade level. More educational status of the household head positively and significantly affects household food and livelihood security [68]. Education level could be correlated to the wealth status of the household. Of the total, about $69.29 \%$ of the farmers had perceived to be under poor wealth status, whereas 7.14\% were categorized in rich class. Land holding size is the most important indicators for wealth status categories of the local farmers. From the total, $54.43 \%$ of the farmers are cultivated both owned and rented farmland, and $42.14 \%$ household cultivated owned farmlands. Labor is one of the human capitals for livelihood development of the farm household. The majority respondents (54.29\%) composed from 3 to 4 productive labor sizes. Productive labour size strongly correlated to more income and livelihood development at household level $[61,68]$. In association with this, of the total about 53.57\% respondents composed from 5 to 6 family members. The average family size in Ethiopia is 4.5 . 
Table 1. Socio-economic characteristics of the respondents $(n=280)$

\begin{tabular}{llccc}
\hline Variable & Category & Percentage (\%) & Mean & St. dev \\
\hline Age & - & - & 44.27 & 9.23 \\
Farming experience (Years) & - & - & 25.44 & 9.35 \\
Gender & Male & 81.43 & & \\
Education status & Female & 18.57 & \\
& Illiterate & 22.14 & \\
Family size & Read and write & 47.14 & \\
& Primary & 21.43 & \\
Productive household size & Secondary and above & 9.29 & \\
& $2-4$ & 27.86 & \\
& $5-6$ & 53.57 & 18.57 & \\
Wealth status & 7 and more & 36.43 & \\
& $1-2$ & 54.29 & \\
Land ownership status & $3-4$ & 9.29 & \\
& 5 and more & 69.29 & \\
& Poor & 23.57 & \\
& Moderate & 7.14 & \\
& Rich & 42.14 & \\
& Self-Owned & 3.43 & \\
& Rented & 54.43 & \\
\hline
\end{tabular}

\subsection{Farmers' perception on the relative weight of indicators for household resilience capacity}

For this study, adaptive capacity is the household's ability to adapt to climate change, risks of productive assets, social-related shocks, and decline of productivity as a result of severe land degradation. Results in Figure (3) indicate that adaptive capacity was the first contributing factor to household resilience for livelihood security. The average value of adaptive capacity was increased by 0.15 when compared to the average value of the resilience capacity index (2.88). Adaptive capacity can be developed through enabling institutional arrangement. Table 2 discloses that from adaptive capacity indicators, farmer knowledge and ability to respond to the risk was the first perceived importance $(\mathrm{RW}=0.182)$ for household resilience capacity of smallholder farmers. More understanding of risks nature, indigenous knowledge to the environment, and able to learn from productive technologies could be the most important to cope-up with shocks and household insecurity. The weighted score results reveal that sustainable management of the farming system (0.584), and farmers' knowledge and ability to respond to the risk (0.557) were the first and second perceived important factors, respectively for household resilience to livelihood insecurity (Table 2).

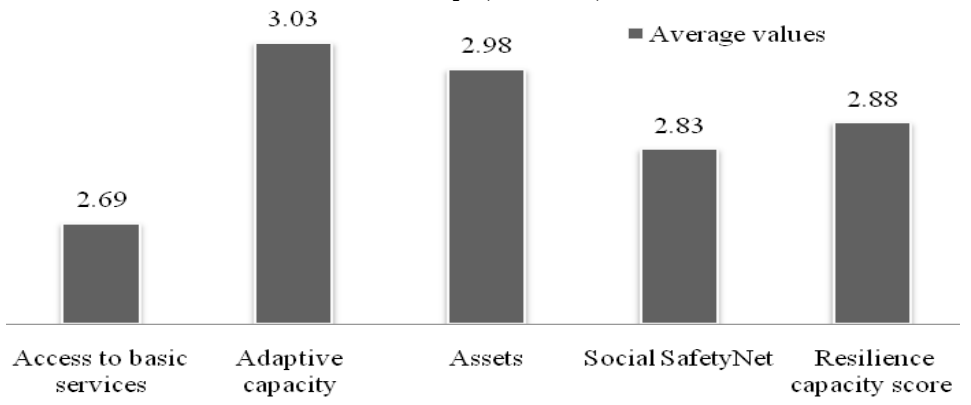

Figure 3. The average score of pillars, and resilience capacity of household $(n=280)$

Results in Figure (3) indicate that asset ownership was the second contributing factor to household resilience. The average value of asset possession was increased by 0.1 when compared to the average value of the resilience capacity index. From asset possession indicators, precautionary saving performance (RW=0.267 \& $\mathrm{WS}=0.863$ ) was the most perceived important indicator to household resilience capacity (Table 2). It scored the highest average value for household resilience when compared to other indicators of asset possession factor. The better saving performance could result in more diversified income activities, and then higher income during the post-shock recovering phase [35]. An intensified livestock farming ( $\mathrm{RW}=0.246 \& \mathrm{WS}=0.74)$ was the second important indicator and had scored more average value to contribute to high household resilience capacity. 
Table 2. Description of the indicators based on the ranking method of relative weights (importance) $(\mathrm{n}=280)$.

\begin{tabular}{lllll}
\hline Pillars & Indicators & \multicolumn{3}{c}{ Mean values } \\
\cline { 3 - 4 } & & RW & AS(SD) & WS \\
\hline Access to & Access to water (AW) & 0.154 & $2.69(0.96)$ & 0.425 \\
basic & Access to saving institution (ASI ) & 0.14 & $2.6(0.83)$ & 0.369 \\
services & School access (SA) & 0.148 & $2.78(0.83)$ & 0.413 \\
(ABS) & Access to health extension (AHE ) & 0.146 & $2.62(0.86)$ & 0.384 \\
& Access to market \& transport (AMT) & 0.202 & $2.46(0.87)$ & 0.497 \\
& Access to the irrigation practice (AIP) & 0.21 & $2.92(1.25)$ & 0.6 \\
Adaptive & Knowledge and ability to respond to risk (KRisk) & 0.182 & $3.04(1.02)$ & 0.557 \\
capacity & Educational level (EDUC) & 0.172 & $2.78(0.88$ & 0.475 \\
(AC) & Labor productivity (LP) & 0.157 & $2.88(0.81)$ & 0.456 \\
& Sustainable management of the farming system (SMFS) & 0.171 & $3.16(1.21)$ & 0.584 \\
& Familiar with practical technologies (FPAT) & 0.173 & $3.38(1.2)$ & 0.552 \\
Asses & Diversification of income activities (DIA) & 0.145 & $2.79(0.86)$ & 0.402 \\
possessio & Intensified livestock farming (ILF) & 0.267 & $3.11(1.43)$ & 0.863 \\
n (AP) & Tree plantation (TP) & 0.246 & $3.02(1.02)$ & 0.74 \\
& Cultivate adequate fertile cropland (CAFL) & 0.245 & $2.93(1.2)$ & 0.719 \\
Social & Couple agreement and honesty on decision (CUHDM) & 0.241 & $2.68(0.83)$ & 0.655 \\
safety net & Social network development (SND) & 0.378 & $3.14(1.16)$ & 1.17 \\
(SSN) & Safety net program participation (SNPP) & 0.363 & $2.88(1.13)$ & 1.05 \\
\hline
\end{tabular}

Note: AS- Actual score; SD- Standard deviation; RW- Relative weight; and WS- Weighted score.

Table 2 shows that from social safety-net indicators, couple mutual understanding and agreement on decision making $(\mathrm{RW}=0.378 \& \mathrm{WS}=1.17)$ was assigned the first perceived contributing factor to the high capacity of household resilience. Next to this, social network development $(\mathrm{RW}=0.363 \& \mathrm{WS}=1.05)$ was the second important to the more household resilience capacity of smallholder farmers.

Basic services indicators, including access to irrigation practice ( $\mathrm{RW}=0.21$, \& WS=0.6), followed by access to transport and market $(\mathrm{RW}=0.2, \& \mathrm{WS}=0.497)$ were the most perceived important for more household resilience capacity (Table 2). These services could support smallholder farmers to develop the capacity for generating income from assets, and to reduce risk exposure [35]. The highest average values of resilience index were observed for access to irrigation practice when compared to other basic services indicators.

\subsection{Livelihood resilience across agro-ecologies}

Table 3. Comparison of resilience index across agro-ecologies and extension package $(n=280)$

\begin{tabular}{llccc}
\hline Variable & Categories & Rank sum & chi-squared & P-value \\
\hline \multirow{3}{*}{ Agroecologies } & Kola & 7098 & & \\
& Woina-dega & 19539 & 18.04 & $<0.001$ \\
& Dega & 12144 & & \\
\hline
\end{tabular}

The household resilience index differed across agro-ecologies (Table 3). Resilient households were significantly higher at $\mathrm{P}<0.001$ in woina-dega and dega than kola. Kola agroecology is the most vulnerable area to livelihood insecurity because of severe land degradation, climate variability, and drought. The lowland or kola agroecological zone was more susceptible to climate variability and change due to lack of access to basic services, low level of diversification of income activities, and lack of available technologies [34, 61]. Weak social networks, severe land degradation, and low assets possession in the kola agroecology result in the highest exposure and sensitivity, the lowest adaptive capacity and the most susceptible livelihood as compared to other agroecologies [93, 61]. In the lowland agroecology erratic rainfall and high temperature during growing season, and invasive crop pests could result in crop failure and reduction of productivity, indicating more sensitive (61). The highest prevalence of food insecurity was observed in the kola agroecology compared to other agroecologies [6]. 


\subsection{Determinants of household resilience to livelihood insecurity}

Four components were extracted based on the analysis of the eigenvalues (Table 4). These components explain $79.94 \%$ of the total variance. The relative size of the factor loading adaptive capacity, followed by assets possession had more significant implications on household resilience to livelihood insecurity.

Table 4. Correlation matrix used for Household Resilience Index (HRI)

\begin{tabular}{lcccc}
\hline \multicolumn{1}{c}{ Variables } & Initial & Extraction & component factors & correlation with HRI \\
\hline Basic services(BS) & 1.00 & 0.765 & 0.875 & $0.86^{*}$ \\
Adaptive capacity(AC) & 1.00 & 0.874 & 0.935 & $0.93^{*}$ \\
Assets Possession (AP) & 1.00 & 0.821 & 0.906 & $0.92^{*}$ \\
Social safety net(SSN) & 1.00 & 0.738 & 0.859 & $0.87^{*}$ \\
Total & & & 3.575 & \\
\hline
\end{tabular}

Eigenvalue variances $(\%)=79.94$

Kaiser-Meyer-Olkin(KMO) measure of sampling adequacy $=0.84$

Bartlett's test of Sphericity, Chi-Square $=816.53$, p-value $=0.000$

Extraction method: principal component analysis

* represents correlation at $\mathrm{P}<0.001$ significant level.

Based on the result presented in Table 4, equation (5) is rewritten to estimate HRI:

$\mathrm{BS} * 0.875+\mathrm{AC} * 0.935+\mathrm{AS} * 0.906+\mathrm{SSN}^{*} 0.859$

The measure of the adequacy of the Kaiser-Meyer-Olkin (KMO) sampling is 0.84 (above the recommended value of 0.5 ); disclosing that the sample is suitable and the variables are relevant for principal components analysis. Bartlett's test of Sphericity is significant at $\mathrm{P}<0.001$ and chi-square $=816.53$, indicating that the variables are strongly correlated to provide a reasonable basis for principal components analysis. Basic services, adaptive capacity, assets and social safety net were positively correlated and had the significant dimensions of household resilience to livelihood insecurity (Table 4).

The household resilience index as the dependent variable was regressed using the structural equation model at the aggregate (Table 5) and disaggregates (Table 6) levels against the explanatory variables. Adaptive capacity, assets, and basic services pillar had positive and significant $($ at $\mathrm{P}<0.001)$ influence on household resilience to livelihood insecurity. The beta coefficient of adaptive capacity $(\beta=0.39)$, followed by assets possession $(\beta$ $=0.26$ ) had the most important dimension and contributed more to determine household resilience to livelihood insecurity. This implies that the more adaptive capacity and the more assets a household possesses could significantly contribute to the higher capacity of household resilience for livelihood security. Adaptive capacity was the most decisive factor responsible for household resilience to food insecurity [38, 57, 19, 40, 48], and multidimentional poverty reduction [51]. The adaptive capacity in turn depends on the level of assets possessed at household level [19]. The households that possessed more assets were more resilient to food insecurity [22].

Table 5. Structural equation modeling results (aggregated)

\begin{tabular}{lccccc}
\cline { 1 - 4 } Variables & \multicolumn{2}{c}{ Unstandardized Coefficients } & \multicolumn{2}{c}{ Standardized Coefficients } & \multirow{2}{*}{ VIF } \\
\cline { 1 - 3 } Constant & beta & SE & beta & SE & \\
Basic services(BS) & 2.88 & 0.03 & $3.81^{*}$ & 0.14 & \\
Adaptive capacity(AC) & 0.18 & 0.03 & $0.23^{*}$ & 0.05 & 1.51 \\
Assets(AS) & 0.29 & 0.04 & $0.39^{*}$ & 0.04 & 1.69 \\
Social safety net(SSN) & 0.2 & 0.04 & $0.26^{*}$ & 0.05 & 1.66 \\
\cline { 1 - 3 } & 0.01 & 0.03 & 0.01 & 0.04 & 1.13 \\
\hline
\end{tabular}

Note: VIF-variance inflation factor; SE-standard error;

* represents correlation at $\mathrm{P} \leq 0.001$ significant level

The variance inflation factor (VIF) results in Table 5 depicts that there was no multicollinearity problem in the analysis.

\section{Adaptive capacity}

Six indicators measured the adaptive capacity pillar (Table 2). Three adaptive capacity indicators, including sustainable management of the farming system, diversification of income activities, and familiarity with practical technologies had a significant influence on household resilience to livelihood insecurity (Table 6).

Sustainable management of the farming systems had a greater likelihood of determining the adaptive capacity and crop productivity for livelihood security. Safeguarding the long-term productivity of farmland is a fundamental prerequisite to securing multidimensional agriculture and resilient livelihoods of rural communities 
since agricultural livelihood and land are interdependent [39, 40]. Maximizing the productivity of existing agricultural land through sustainable management practices is imperative to guarantee food security for the increasing population [22, 84, 78]. Sustainable management of farming systems commonly integrates agronomic, physical, and vegetative practices. For example, in the farming system, conservation agriculture containing straw mulching, minimum tillage, and legume-cereal crop rotation significantly improved crop yield $[78,98,46,70,101]$. Conservation agriculture could be more effective in sustaining high crop yield when it is supplemented by the combined application of fertilizer and manure or compost [66]. The combination of conservation agriculture and manure or composting reduces the chemical fertilizer requirement for crop production [46]. Nutrient use efficiency and water use efficiency are effectively protected in the fields where terraces are well constructed, stabilized with vegetative practices, properly maintained, and complemented with appropriate practices of drainage ditches [13, 90, 5, 47, 39]. Planting multipurpose grasses and trees on unutilized soil bunds for fodder or fuel-wood harvesting (scarce supply in Ethiopia highlands) could offset crop yield loss owing to the area occupied by bunds $[13,5,39)$. Therefore, sustainable management of the farming system through integrating agronomic, vegetative, and structural practices could contribute to increasing the productivity of cropland and livestock for more diversification of income activities at the household level.

Diversification of income activities has been determining the adaptive capacity pillar of household resilience. It is the main viable strategy to achieve the sustainable livelihood of smallholder farmers $[15,57,16,70,66,40]$. Household income, landholding size, exposure to extension contacts, agroecological suitability are related to the likelihood of diversification of smallholder income activities [64]. Diversification of income activities can be influenced by the ability to adapt productive technologies.

The ability to adapt productive technologies and skills has determined the development of a more adaptive capacity to shocks and risks. Familiarity with appropriate practical skills in cropland management, yield harvesting, livestock grazing, beehive management, plantation practice, and horticultural management significantly contributes to farmers' household resilience. Farmers' capacity, interest, and adaptability to valueadded practices and new technologies were very essential to the more resilient household [83]. Knowledge and experience of farmers on recurrent drought and the use of climate-smart technologies like drought-tolerant crop and livestock varieties positively contribute to building household resilience [159, 63, 43]. An understanding of how the system responds to change and implementing appropriate adaptation strategies often comes from experience and local knowledge of past responses to extreme events or stresses [24, 43].

Table 6. Structural equation modeling results (disaggregated)

\begin{tabular}{|c|c|c|c|c|c|c|}
\hline \multirow[t]{2}{*}{ Component } & \multirow[t]{2}{*}{ Variables } & \multicolumn{2}{|c|}{ Unstandardized Coefficients } & \multicolumn{3}{|c|}{ Standardized Coefficients } \\
\hline & & beta & SE & beta & SE & sig. \\
\hline \multirow{5}{*}{$\begin{array}{l}\text { Basic } \\
\text { services }\end{array}$} & Access to saving institution & 0.11 & 0.04 & 0.12 & 0.15 & 0.193 \\
\hline & School access & 0.05 & 0.05 & 0.05 & 0.05 & 0.345 \\
\hline & Access to health extension & 0.08 & 0.04 & 0.09 & 0.05 & 0.063 \\
\hline & Market \& transport access & 0.13 & 0.04 & 0.019 & 0.12 & 0.102 \\
\hline & Irrigation access & 0.082 & 0.01 & 0.05 & 0.01 & 0.001 \\
\hline \multirow[t]{6}{*}{$\begin{array}{l}\text { Adaptive } \\
\text { capacity }\end{array}$} & $\begin{array}{l}\text { Knowledge on risk and able to } \\
\text { responds }\end{array}$ & 0.01 & 0.04 & 0.02 & 0.06 & 0.791 \\
\hline & Educational level & -0.01 & 0.04 & -0.02 & 0.05 & 0.744 \\
\hline & Labour productivity & 0.06 & 0.04 & 0.08 & 0.06 & 0.166 \\
\hline & $\begin{array}{l}\text { Familiar to practical and } \\
\text { adaptable technologies }\end{array}$ & 0.18 & 0.05 & 0.75 & 0.06 & 0.062 \\
\hline & $\begin{array}{l}\text { Sustainable management of } \\
\text { farming system }\end{array}$ & 0.075 & 0.02 & 0.019 & 0.01 & 0.002 \\
\hline & $\begin{array}{l}\text { Diversification of income } \\
\text { activities }\end{array}$ & 0.076 & 0.03 & 0.017 & 0.02 & 0.001 \\
\hline \multirow{4}{*}{$\begin{array}{l}\text { Assets } \\
\text { possession }\end{array}$} & Precautionary saving behavior & 0.188 & 0.01 & 0.317 & 0.01 & 0.001 \\
\hline & Intensified livestock farming & 0.05 & 0.04 & 0.125 & 0.013 & 0.001 \\
\hline & Tree plantation & 0.06 & 0.03 & 0.07 & 0.04 & 0.071 \\
\hline & $\begin{array}{l}\text { Cultivate adequate fertile } \\
\text { farmland }\end{array}$ & 0.101 & 0.02 & 0.063 & 0.014 & 0.001 \\
\hline \multirow[t]{3}{*}{$\begin{array}{l}\text { Social } \\
\text { safety net }\end{array}$} & $\begin{array}{l}\text { Couple agreement and honesty } \\
\text { on decision \& management }\end{array}$ & -0.01 & 0.03 & -0.007 & 0.04 & 0.853 \\
\hline & Social network development & 0.189 & 0.121 & 0.108 & 0.014 & 0.01 \\
\hline & Safety net & 0.188 & 0.012 & 0.03 & 0.04 & 0.423 \\
\hline constant & & 0.641 & 0.19 & 0.84 & 0.26 & 0.002 \\
\hline
\end{tabular}




\begin{abstract}
Assets possession
The asset possession pillar was the second contributing factor to more household resilience. Three asset indicators, such as cultivating adequate fertile farmland, saving performance and intensified livestock husbandry had explained household resilience to livelihood insecurity at $\mathrm{P}<0.001$ significant level (Table 6).
\end{abstract}

Saving in the form of cash and liquid assets in different institutions and associations is one of the best mechanisms for addressing assets development and livelihood security. Saving enables one to cope with illness and crises, and invest income-generating activities for regular income [24]. Households' risk management behavior through precautionary saving as an ex-ante strategy is more likely contributed to resilience to shocks of livelihood security in northwest Ethiopia [16, 51]. Saving behavior at the household level was significantly influenced by extension contact frequency and access to market information [10]. It was also determined by larger productive labor size, diversification into non-farming activities, education level, and distance of saving institutions [100]. A large number of households do not have long-term saving motives and their saving behavior is affected by extravagant cultural activities and lack of awareness in Gojam, Northwest Ethiopia [91]. Socio-cultural activities, such as locally named Tezkar, Mahiber, Senbete, and early marriage ceremony in the winter season are major causes of the economic crisis of smallholder farmers [4]. The unexpected expense in cash and other resources is commonly observed in the local communities of the study district and other areas of northwest Ethiopia. Farmers revealed that avoiding disadvantageous socio-cultural activities is considered as one major contributing factor to improving saving at the household level. Awareness creation and development on saving behavior and avoiding extravagant socio-cultural activities should be encouraged through collaborative efforts of the religious, institutional, and legal frameworks [100, 4, 10, 91]. Short and long-term planning can be the basis to effectively manage agricultural yields. Farmers discussed that short and long-term planning development and effective management of agricultural yield are important for achieving livelihood development. Smallholder farmers' aspiration for livelihood improvement is the most important determinant of household resilience for livelihood security [43]. Households saving higher cash income have developed better ability and capacity to mitigate disaster, to build human capital like education, and to diversify their livelihoods into non/off-farm activities $[63,16]$. More savings could intensify livestock husbandry, and enable to possession of more fertile cultivated land.

Holding more livestock and cultivating larger farmland are correlated positively and significantly to the dynamics of building resilience for food security [15]. Stark et al. [88] noted that a higher intensity of croplivestock integration flow improves the efficiency of the system while a more complex and homogenous flow network improves the resilience of the system. From livelihood assets, improved livestock husbandry contains poultry, apiary, fattening practice (of cattle, sheep, \& goat), and horse and donkeys for transportation. It could be promoted as a preferred livelihood activity as it is a superior income source due to higher returns and lower variable costs [12]. Livestock husbandry contributes more (sell milk and fattened livestock to meat) to total household income, constitutes an important safety net during times of economic hardship, is used as traditional means of transportation (donkey and horse), and draught power for farming, and produce dung for household energy and as organic fertilizer [12,35]. The value of productive livestock husbandry is found to be significantly associated with the probability of a household generating sustainable livelihood [15, 44, 59]. In kola agroecology, livestock farming is more likely to contribute to household resilience than woina-dega and dega agro-ecologies. Integration of the crop-livestock mixed farming system with plantation produces greater agro-biodiversity for more diversified livelihood and income [31].

Plantation assets significantly (at $\mathrm{P}<0.1$ ) explained household resilience for livelihood security (Table 6). Plantation of exotic eucalyptus and acacia species are the most dominant and fast-growing plants (harvest from 4 to six years after planting) for woodlot forestry in diverse climatic and soil characters [99, 29]. When the cultivated field is unproductive for crop production, farmers often preferred to convert it into eucalyptus tree plantation in the face of the fast-rising price per tree for construction materials in the urban area. At the household level trees are planted for cash income, construction, fodder, and fuelwood purposes. The expansion of plantation could provide short-term economic benefits, generates job opportunities for the landless, and enables farmers to diversify their livelihoods [99]. Rural households earned positive financial returns from the plantation of acacia and eucalyptus species with seven-year rotations [29]. Integrating fast-growing trees with annual crops possibly maximize ecological and economic benefits. Using planted trees for fuel-wood replaces cattle-dung and maize straw can be used as organic manure to the productivity of the agricultural field [18]. Acacia plantation on degraded hillsides could enable to ensure livelihood gains of landless farmers under the pressure of an expanding rural population in the northwest highlands of Ethiopia [74]. The plantation system increased household income, created job opportunity, improved social lives, and improved degraded soils significantly [73], and contributed to sustainable livelihood of farm household [102]. Plantation multifunctional 
vegetation on the structural conservation segment of croplands and enclosure communal areas should be strengthening by bylaw for livelihood security of smallholder farmers [3]. The combination of complete closing, cut-and-carry grazing system, and plantation of multifunction plants on communal land highly recommend for sustainable mixed farming productivity [32]. Croplands are sometimes converted into eucalyptus tree plantations in particular where cultivated fields are in proximity to the market and easily accessible for transportation. Access to market and transportation services affects the capacity of the household to manage agricultural yield and related risk [63, 59, 8]. In kola agroecology, plantations of fruit plants substantially contribute to household resilience for livelihood security.

\section{Access to basic services}

From basic services, access to irrigation explained significantly for household resilience to livelihood insecurity (Table 6). In the dry-sub humid area where erratic rainfall pattern is observed largely, irrigation access is very essential to produce diverse crops, vegetables, and fruits, and livestock fodders. Access to traditional irrigation for cereal crop, vegetable, and fruit productions contributes to increased household income, the daily calorie intake, and livelihood development $[14,55]$. It is one of the major adaptation options to limit the negative impacts of climate variability [40]. Access to irrigation is negatively determined by distance from irrigable farm plot to water source and distance from market [62].

\section{Social safety-nets}

From social safety net pillar, social network development significantly (at $\mathrm{P}<0.01$ ) influenced to household resilience for livelihood security (Table 6). Social networks mediate access to labor exchange, physical assets, and micro-credit schemes. Development of social networks through membership in the cooperative, urban linkage, labor sharing groups, saving, and credit association was found to have a significant positive impact on farmers' livelihood diversification [16]. More social networks determine the ability to practice and regularly maintain labor-intensive land management practices for more livestock husbandry, crop production, and plantation practices $[92,62]$.

\section{Conclusion}

The study aims to identify factors determining household resilience to livelihood insecurity under the croplivestock mixed farming systems in Goncha district, Northwest highlands of Ethiopia. The results disclosed that adaptive capacity, followed by asset possession had significant and positive impacts on household resilience to livelihood insecurity. Sustainable management of the farming systems, diversification of income activities, and familiarity with practical and adaptable technologies were the most important determinants explaining adaptive capacity. Assets indicators, including intensified livestock husbandry, cultivation of fertile farmland, improved saving behavior and tree plantation were significantly and positively explained assets possession factor. Moreover, access to irrigation practice and social network development significantly explained household resilience. Therefore, agricultural extension packages should scale up sustainable management of the farming system, saving behavior, means of income diversification, adaptable technologies, and agroforestry in addressing household resilience to livelihood insecurity of smallholder farmers across diverse agro-ecologies.

\section{Declaration}

Ethics approval and consent to participate: The study design was fully explained to the respondents for gaining consent. Data generated from a participant were kept confidential and all informants are acknowledged. Consent for publication: Not applicable.

Availability of data and materials: The data are available from the corresponding author.

Competing interest: The authors declare that there is no conflicting interest

Funding: The study carried out with specific funding from Debre Markos University

Author's contribution; Ermias Debie developed the study proposal, collected data, performed the analysis and interpreted the data, wrote the manuscript, and acted as the corresponding author. Amare Wubishet assisted in collecting data, analyzing, and interpret the data. All authors read and approved the final manuscript.

Acknowledgments: The authors acknowledged all respondents and data collectors for their willingness to participate in this study; and Debre Markos University for funding the study.

\section{References}

1. Abebe, G. Cash-for-work and food-for-work programmes' role in household resilience to food insecurity in southern Ethiopia. Development in Practice 2020, 30(8). https:// doi.10.1080/09614524.2020.1747398

2. Abeje, M.T.; Tsunekawa, A.; Haregeweyn, N.; Nigussie, Z.; Adgo, E.; Ayalew, Z.; Tsubo, M.; Elias, A.; Berihun, D.; Quandt, A.; Berihun, M.L.; Masunaga, T. Communities’ Livelihood Vulnerability to Climate Variability in Ethiopia. Sustainability 2019, 11, 6302. https://doi.org/10.3390/su11226302 
3. Adego, T.; Simane, B.; Woldie, G.A. Sustainability, institutional arrangement, and challenges of community-based climate-smart practices in northwest Ethiopia. Agriculture \& food security, 2018, 7:56. https://doi.org/10.1186/s40066-018-0206-0

4. Adigeh,Y. The theological interpretation of Tezkar and its economic impact in east Gojam. Zena-lisan 2017,XXVI (1).

5. Adimassu, Z.; Langan, S.; Johnston, R.; Mekuria, W.; Amede, T. Impacts of soil and water conservation practices on crop yield, run-off, soil loss, and nutrient loss in Ethiopia: review and synthesis. Environmental management 2017, 59:87-101. https://doi.org/10.1007/s00267-016-0776-1

6. Alemu, Z.A.; Ahmed, A.A.;Yalew, A.W.; Simanie, B. Spatial variations of household food insecurity in East gojam zone, Amhara region, Ethiopia: implications for agroecosystem-based interventions. Agriculture \& food security 2017, 6:36. https://doi.10.1186/s40066-017-0113-9

7. Alinovi, L.; Mane, E.; Romano, D. Measuring Household Resilience to Food Insecurity: Application to Palestinian Households. In BenedettiR.BeeM.EspaG.PiersimoniF. (Eds.), Agricultural Survey Methods. Chichester, UK: John Wiley \& Sons, Ltd., 2010, https://doi.org/10.1002/9780470665480.ch21

8. Alinovi, L.; Mane, E.; Romano, D. Measuring household resilience to food security: Application to Palestinian households.EC-FAO food Security programme linking information and decision making to improve food security. EC-FAO Food Security Program Rom, 2009 . www.foodsec.org

9. Ananda, J.; Herath, G. Analysis of forest policy using multi-attribute value theory. Using multi-criteria decision analysis in natural resource management, Routledge, 2017: 27-56.

10. Asare, E.; Segarra, E.; Gertrude, N.; Asiseh, F. Explaining the saving behavior of households in Ethiopia, Africa article. Applied Economics and Finance, 2018, 5(2), ISSN 2332-7294. https://doi.org/10.11114/aef.v5i2.2923

11. Asfaw, A. Bantider, A.; Simane, B. Hassen, A. Smallholder farmers livelihood vulnerability to climate change induced hazars:agroecology-based comparative analysis in northcentral Ethiopia (Woleka subbasin). Heliyon 2021(7) e06761. https://doi.org/10.1016/j.heliyon.2021.e06761

12. Ashley, K.; Harrison, H.; Hok, P.; Sothoeun, S.; Robert, J.S.; Windsor, A.P.; Bush, D.R. Livestock and livelihoods of smallholder cattle-owning households in Cambodia: the contribution of on-farm and off-farm activities to income and food security. Tropical animal health and production 2018.

https://doi.org/10.1007/s11250-018-1615-6

13. Asmare,T.; Derebe, A.; Yitaferu, B.; Steenhuis, T.S.;Hurni, H.; Zeleke, G. Combined effect of soil bund with biological soil and water conservation measures in the northwestern Ethiopian highlands. Ecohydrology and Hydrobiology 2014, (14(3), 192-201

14. Assan, J.K.; Regassa, F. Livelihood Impacts of Environmental Conservation Programs in the Amhara Region of Ethiopia, Journal of Sustainable Development, 2013, 6(10).

15. Asmamaw, M.; Mereta, S.T.; Ambelu, A. Exploring households' resilience to climate change-induced shocks using Climate Resilience Index in Dinki watershed, central highlands of Ethiopia. PLoS ONE 2019, 14(7): e0219393. https://doi. org/10.1371/journal.pone.0219393

16. Awoke,W. Determinants and challenges of rural livelihood diversification in Ethiopia: Qualitative review. Journal of agricultural extension and rural development 2019, 11(2), 17-24. https://doi. org/ 10.5897/JAERD2018.0979

17. Barrett, C.B.; Constas, M.A. Toward a theory of resilience for international development applications. Proceedings of the National Academy of Sciences 2014, 111(40), 14625-14630.

18. Bayle, G. K. Ecological and social impacts of eucalyptus tree plantation on the environment. J.biodivers.econserv.bioresour.manage. 2019, 5(1), 93 https://doi.org/10.3329/jbcbm.v5i1.42189

19. Bekele, M.; Bezabih, M.; Elias, H.; Fisker, P.; Gebrehiwot, T.; Kuma, T.; MekashaT.; Mekonnen, A.; Tarp, F.; Teklewold, H. Building Resilience to Climate Change in Ethiopia What do we know so far? Development Economics Research Group Working Paper Series 2020, 01-2020

20. Béné, C.; Wood, R.G.; Newsham, A.; Davies, M. Resilience: new utopia or new tyranny? Reflection about the potentials and limits of the concept of resilience with vulnerability reduction programs. IDS Working Papers 2012(405), 1-61.

21. Biggs. R.; Schlüter, M.;Schoon, M.L. Principles for building resilience: Sustaining ecosystem services in social-ecological systems, Cambridge University Press 2015.

22. Boukary, A. G.; Diaw, A.; Wunscher, T. Factors affecting rural households' resilience to food insecurity in Niger. Sustainability 2016, 8(181). https://doi.org/10.3390/su8030181

23. Braimoh, A.K.;Vlek, P.L. Impact of land use on soil resources. Land Use and Soil Resources, Springer 2008, 1-7.

24. Chakma, N. The saving and investment behavior of extreme poor marma community households in resilience-building: A case study on Green Hill village savings and loan association intervention in the Chittagong Hill tracts. Technical reports 2013. https://doi.org/ 10.13140/RG.2.2.33764.63365 
25. Chuku, C.A., Okoye, C., 2009. Increasing resilience and reducing vulnerability in sub-Saharan African agriculture: Strategies for risk coping and management. African Journal of Agricultural Research 4(11), 1524-1535.

26. Cochran, W.G. Sampling techniques, John Wiley \& Sons 2007.

27. Colls, A.; Ash, N.; Ikkala, N. Ecosystem-based Adaptation: a natural response to climate change. Gland, Switzerland: IUCN. 2009, 16pp.

28. Constas, M.; Frankenberger, T.; Hoddinott, J. Resilience measurement principles: Toward an agenda for measurement design. Food Security Information Network, Resilience Measurement Technical Working Group 2014,Technical Series 1.

29. Cooper, E.; Boyden, J. Questioning the power of resilience: are children up to the task of disrupting the transmission of poverty? Chronic Poverty Research Centre Working Paper 2007, (73).

30. Cooper, P.J.M.; Dimes, J.; Rao, K.P.C.; Shapiro, B.; Shiferaw, B.; Twomlow, S. Coping better with current climatic variability in the rain-fed farming systems of Sub-Saharan Africa: A dress rehearsal for adapting to future climate change? Global theme on Agroecosystem reports No.27. PO Box 29063-00623, Nairobi, Kenya: International Crops Research Institute for the semiarid Tropics 2006, 24pp

31. Cordova, R.; Hogarth, N.J.; Kanninen, M. Sustainability of smallholder livelihoods in the Ecuadorian Highlands: A comparison of agroforestry and conventional agricultural systems in the indigenous Territory of Kayambi people. Land 2018, 7,45.doi:10.3390/land7020045

32. Debie, E.; Singh, K. N. Performance of common pool resources management in the mixed farming system in Goncha district, northwest highlands of Ethiopia. Environment, development and sustainability (2020). https://doi.org/10.1007/s10668-020-00996-4

33. Debie, E.; Singh, K.N.; Belay, M. Effect of conservation structures on curbing rill erosion in microwatershed, northwest Ethiopia. International soil and water conservation research 2019, 7: 239-247. https://doi.org/10.1016/j.iswcr.2019.06.001

34. Dendir, Z.; Simane, B. Livelihood vulnerability to climate variability and change in different agroecological zones of Gurage administrative zone, Ethiopia. Progress in Disaster science 3 (2019)100035. http://dx.doi.org/10.1016/j.pdisas.2019.100035

35. De-ponta, T.; Mandisa, C.; Thondhlana, G.; Velded, P. Livestock income and household welfare for communities adjacent to the great fish river nature reserve, South Africa. Environmental development 2020, 33,100308. https://doi.org/10.1016/j.envdev.2020.100508

36. Devereux, S. Livelihood insecurity and social protection: A re-emerging issues in rural development. Development policy review, 2001, 19 (4), 507-519

37. DFID. Defining disaster resilience: A DFID approach paper. London: Department for International Development (DFID) 2011

38. Dhraief, M.Z.;Dhehibi, B.; Hassen, H.D.; Zlaoui, M.; Khatoui, C.; Jemni, S.; Jebali, Q.; Rekik, M. Livelihoods strategies and household resilience to food insecurity: A case study from rural Tunisia. Sustainability 2019, 11(907). https://doi.org/10.3390/su11030907

39. Ehrensperger, A.; Ott, C.; Wiesmann, U.M. Eastern and Southern Africa Partnership Program: Highlights from 15 years of joint action for sustainable development, Centre for Development and Environment (CDE); Bern Open Publishing (BOP) 2015

40. Etana, D.; Snelder, D.J.R.M.; van Wesenbeeck, C.F.A.; de Cock Buning, T. The Impact of Adaptation to climate Change and Variability on the Livelihood of Smallholder Farmers in Central Ethiopia. Sustainability 2021, 13, 6790. https:// doi.org/10.3390/su13126790

41. Fan Y.; Chen J.; Shirkey, G.;John, R; Wu, S.R.; Park, H.; Shao., C. Applications of structural equation modeling (SEM) in ecological studies: an updated review. Ecological Processes 2016, 5:19.

https://doi. 10.1186/s13717-016-0063-3

42. FAO. RIMA-II Analyzing Resilience for better targeting and action. Food and Agriculture Organization of the United Nations Rome 2016, ISBN 978-92-5-109235-4

43. Frankenberger, T.; Nelson, S. Background paper for the Expert Consultation on Resilience Measurement for Food Security. February 15, 2013, TANGO International

44. Frankenberger,T.R.;Sutter,P.; Teshome, A.; Aberra, A.; Tefera, M.; Tefera, M.; Seyoume, A.; Bernard, T.; Spangler, T.; Ejigsemahu, Y.Ethiopia: The Path to Self-resiliency. Volume I: Final Report. Chf - Partners in Rural Development on Behalf of: Canadian Network of Ngos in Ethiopia (Cango) 2007

45. Frankenberger, T.R.; Drinkwater, M.; Maxwell, D. Operationalizing household livelihood security. Proceeding from the forum on operationalizing sustainable livelihoods approaches Pontignano (Siena) 7-11 March 2000

46. Franke, A.C.; van den Brand, G.J.; Vanlauwe, B.; Giller, K.E. Sustainable intensification through rotations with grain legumes in sub-Saharan Africa: A review. Agriculture, ecosystems and Environment 2018, 261,172-185 
47. Gathagu, J.N.; Sang, J.K.; Maina, C.W. Modeling the impacts of structural conservation measures on sediment and water yield in Thika-Chania catchment, Kenya. International soil and water conservation research 2018, 6, 165-174. https://doi.org/10.1016/j.iswcr.2017.12.007

48. Gebre, G.G.; Rahut, D.B. Prevalence of household food insecurity in East Africa: Linking food access with climate vulnerability. Climate Risk Management 33(2021), 100333.

https://doi.org/10.1016/j.crm.2021.100333

49. Gebre, G.G.; Isoda, H.; Rahut, D.B.; Amekawa, Y.; Nomura, H. Gender differences in agricultural productivity: Evidence from maize farm households in southern Ethiopia. Geojournal (2021), 86:864. https://doi.org/10.1007/s10708-019-10098-y

50. Grace, J.B.; Anderson, M.T.; Olff, H.; Scheiner, S.M. On specification of structural equation models for ecological systems. Ecological monographs 2010, 80(1), 67-87. https://doi. 10.2307/27806874

51. Haile, D.; Seyoum, A.; Azmeraw, A. Does building the resilience of rural households reduce multidimensional poverty? Analysis of panel data in Ethiopia. Scientific African 12, 2021 e00788. https://doi.org/10.1016/j.sciaf.2021.e00788

52. Hedge, N.G. Livestock development for the sustainable livelihood of small farmers. Asian Journal of research in Animal and veterinary science 2019, 3(2), 1-17 Article no. AJRAVS.48871

53. Hurni, H.;Berhanu, D.; Gete, Z. Saving Ethiopians Soils. In Ehrensperger A., Ott, C.,Wiesmann, U. (Ed.). Easter and Southern Africa Partnership Programme: Highlights from 15 years of joint action for sustainable development. Bern, Switzerland: centre for Development and environment (CDE), university of Bern, with Bern open publishing (BOP) 2015, pp23-26.

54. Hurni, H.; Abate, S.; Bantider, A.; Debele, B.; Ludi, E.; Portner, B.; Yitaferu, B.; Zeleke, G. Land degradation and sustainable land management in the highlands of Ethiopia. In: Hurni H, Wiesmann U, editors; with an international group of co-editors. Global Change and Sustainable Development: A Synthesis of Regional Experiences from Research Partnerships. Perspectives of the Swiss National Centre of Competence in Research (NCCR) North-South, University of Bern, Vol. 5. Bern, Switzerland: Geographica Bernensia 2010, pp 187-207. https://boris.unibe.ch/5959/1/Hurni_Land\%20degradation.pdf

55. Jambo, Y.; Alemu, A.; Tasew, W. Impact of small-scale irrigation on household food security: evidence from Ethiopia. Agric \& Food Secur 2021, 10:21. https://doi.org/10.1186/s40066-021-00294-w.

56. Kasie, T.A.;Tsegaye, E.A.; Grandio-Botella, A.; Giménez-García, I. Measuring resilience properties of household livelihoods and food security outcomes in the risky environments of Ethiopia. Journal of Development Studies 2018,7(2):52-80. https://doi.org/10.26754/ojs_ried/ijds.252

57. Kassie, G.; Kim, S.; Francisco, P.; Fellizar, J. Determinant factors of livelihood diversification: evidence from Ethiopia. Cogent Social Sciences 2017, 3, 1369490. https://doi.org/10.1080/23311886.2017.1369490

58. Kiteme, B.; Ehresperger, A. The ngolo farming technology. In Ehrensperger, A., Ott,C. and Wiesmann, U.(ed.). Eastern and Southern Africa partnership programme: highlights from 15 years of joint action for sustainable development. Bern, Switzerland: Centre for Development and Environment (CDE), university of Bern, with Bern open publishing (BOP) 2015, pp 23-26.

59. Liniger, H.; Critchley, W. Safeguarding Water Resources by Conserving Land, Protecting Water. 2008, 6, 129. Manlosa, O.; Hanspach, J.;Schultner, J.; Dorresteijn, I.; Fischer, J. Livelihood strategies, capital assets, and food security in rural southwest Ethiopia. Asia. Food security 2019, 11,167-181. https://doi.org/10.1007/s12571- 018-00883-X

60. Maronna, R.A.; Martin, R.D.; Yohai, V.J.; Salibián-Barrera, M. Robust statistics: theory and methods (with R). Wiley 2018.

61. Maru, H.; Haileslassie, A.; Zeleke, T.; Esayas, B. Analysis of Smallholders' Livelihood Vulnerability to Drought across Agroecology and Farm Typology in the Upper Awash Sub-Basin, Ethiopia. Sustainability 2021, 13, 9764. https:// doi.org/10.3390/su13179764

62. Maxwell, D.; Constas, M.; Frankenberger, T.; Klaus, D.; Mock, M. Qualitative data and subjective indicators for resilience measurement. Resilience measurement technical working group. Technical series no. Food Security Information Network, Rome, 2015.

63. Mayunga, J.S. Understanding and applying the concept of community disaster resilience: a capital-based approach. Summer academy for social vulnerability and resilience building 2007 1(1), 1-16.

64. McCord, P.F.; Cox, M.;Schmitt-harsh, M.; Evans, T. Crop diversification as a smallholder livelihood strategy within semi-arid agricultural systems near Mount Kenya. Land use Policy 2015, 42, 738-750. http://dx.doi.org/10.1016/j.landusepol.2014.10.012

65. Mekonen, A.A.; Berlie, A.B. Rural households' livelihood vulnerability to climate variability and extremes: a livelihood zone-based approach in the North-eastern Highlands of Ethiopia. Ecological Processes, 2021, 10:55. https://doi.org/10.1186/s13717-021-00313-5

66. Melketo, T.A.; Geta, E.; Sieber, S. Understanding livelihood diversification patterns among smallholder farm households in southern Ethiopia. Sustainable agricultural research 2020, 9(1), ISSN 1927-050X EISSN 1927- 0518 . https://doi.org/10.5539/sar.v9n1p26 
67. Mendoza, G.; Macoun, P.; Prabhu, R.; Sukadri, D.; Purnomo, H.; Hartanto, H. Guidelines for applying multi-criteria analysis for the assessment of criteria and indicators. Guidelines for applying multi-criteria analysis for the assessment of criteria and indicators 2000.

68. Mengistu, D.D.; Degaga, D.T.; Tsehay, A.S. Analyzing the contribution of crop diversification in improving household food security among wheat dominated rural households in Sinana District, Bale Zone, Ethiopia. Agric \& Food Secur 2021, 10:7. https://doi.org/10.1186/s40066-020-00280-8

69. Mengistu, F.; Assefa, E. Farmers' decision to adopt watershed management practices in the Gibe basin, Southwest Ethiopia. International soil and water conservation research 2019, 7,376-387

70. Monica, I.; Arizechukwu, C.; Blessing, C.; Olularanti, O. Legume-maize rotation effect on maize productivity and soil fertility parameters under selected agronomics practices in sandy loam soil. Scientific reports 2019, 9, 8539.https://doi.org/10.1038/s41598-019-43679-5

71. Myeki, V.A.; Bahta, Y.T. Determinants of Smallholder Livestock Farmers' Household Resilience to Food Insecurity in South Africa. Climate 2021, 9:117. https://doi.org/10.3390/cli9070117

72. Nelson, S.; Frankenberger,T.; Langworthy, M.; Finan, T.,Bower, T. The Effect of Livelihood Diversity on Recovery and Shock Impact in Ethiopia, Kenya and Uganda. Report prepared by The Technical Consortium, a project of the CGIAR. Technical Report Series 2016, No 2.

73. Nigussie, Z.; Tsunekawa, A.; Hargeweyn, N.;Adgo, E.; Tsuboa, M.; Ayalew, Z.; Abele, S. Economic and financial sustainability of an Acacia-decurrense-based Taungya system for farmers in the upper Blue Nile basin, Ethiopia. Land use policy 2020, 90, 104331. https://doi.org/10.1016/i.landusepol.2019.104331

74. Nigussie, Z.; Tsunekawa, A.; Haregeweyn, N.; Tsubo, M.; Adgo, E.; Ayalew, Z.; Abele, S. The impacts of Acacia decurrens plantations on livelihoods in rural Ethiopia. Land Use Policy 100(2021)104928

75. Noble, M.; Babita, M.; Barnes, H.; Dibben, C.; Magasela, W.; Noble, S.; Ntshongwana, P.; Phillips, H.; Rama, S.; Roberts, B. The provincial indices of multiple deprivations for South Africa 2001. TechnicalReport, 2006, University of Oxford, UK.

76. O'Brien, K. Global environmental change II: from adaptation to deliberate transformation. Progress in Human Geography 2012, 36(5), 667-676.

77. Pimentel, D. Soil erosion: A food and environmental threat. Environment, Development and Sustainability 2006, 8:119-137. https://doi.org/10.1007/s10668-005-1262-8

78. Pretty, J.; Benton, T.G.; Bharucha ,Z.P.; Dicks, L.V.; Flora, C.B.; Godfray, H.C.J.; Goulson, D.; Hartley, S.; Morris, C.; Pierzynski, G.; Prasad, P.V.V.; Reganold, J.; Smith, P.;Thorne, P.; Wratten, S. Global assessment of agricultural system redesign for sustainable intensification. Nature Sustainability 2018, 1,441-446.https://doi.org/10.1038/s41893-018-0114-0

79. Quandt, A. Measuring livelihood resilience: The household livelihood resilience approach (HLRA). World Development 2018, 107: 253-263.

80. Resilience Alliance. Assessing resilience in social-ecological systems: Workbook for practitioners. 2010, Version 2.0. Online: http://www.resalliance.org/3871.php

81. Sagara, B. Resilience Measurement Practical Guidance Note Series 2: Measuring Shocks and Stresses. Produced by Mercy Corps as part of the Resilience Evaluation. Analysis and Learning (REAL) Associate Award 2018.

82. Scoones, I. Sustainable Rural Livelihoods: A Framework for Analysis. IDS Working Paper 2000, 72

83. Sharma, B.R.; Samra, J.; Scott, C.; Wani, S.P. Watershed management challenges improving roductivity, resources, and livelihoods, International Water Management Institute 2005.

84. Smith, P. Soil organic carbon dynamics and land-use change. Land use and soil resources, Springer 2008, 9-22.

85. Snijders, T.A. Power and sample size in multilevel linear models. Encyclopedia of statistics in behavioral science 2005.

86. Solomon, S.; Qin, D.; Manning, M.; Chen, Z.; Marquis, M.; Averyt, K.; Tignor, M.; Miller, H. IPCC fourth assessment report (AR4). Climate change 2007.

87. Speranza, C.I.; Wiesmann, U.; Rist, S. An indicator framework for assessing livelihood resilience in the context of social-ecological dynamics. Global Environmental Change 2014, 28, 109-119.

88. Stark, F.; González-García, E.; Navegantes, L.; Miranda, T.; Poccard-Chapuis, R.; Archimède, H.; Moulin C. Crop-livestock integration determines the agroecological performance of mixed farming systems in Latino-Caribbean farms. Agronomy for Sustainable Development 2018, 38:4. https://doi.org/10.1007/s13593-017-0479-x

89. Stocking, M.A. Tropical soils and food security: The Next 50 Years. Science 2003, 302. https://doi.org/10.1126/science.1088579

90. Subhatu, A.; Lemann, T.; Hurni, K.; Portner, B.; Kassawmar.; Zeleke, G.; Hurni, G. Deposition of eroded soil on terraced croplands in Minchet catchment, Ethiopia Highlands. International soil and water conservation research 2017, 5, 212-220. http://dx.doi.org/10.1016/j.iswcr.2017.05.008 
91. Tariku, T. Saving practices of rural households in Ethiopia: the case of East Gojjam Zone, Amhara regional, Journal of economics and sustainable development 2018, 9:49-54

92. Tefera, N.; Demeke, M.; Kayitakire, F. Building sustainable resilience for food security and livelihood dynamics: the case of farming rural households in Ethiopia, EUR 29111 EN, European Commission, Ispra 2017, ISBN 978-92-79-79830-6. https://doi.org/ 10.2760/973096, JRC110834

93. Tessema, I.; Simane, B. Vulnerability analysis of smallholder farmers to climate variability and change: an agroecological system-based approach in the Finch'a sub-basin of the upper Blue Nile basin of Ethiopia. Ecological Processes 2019, 8:5 https://doi.org/10.1186/s13717-019-0159-7

94. Teshome, A.; De Graaff, J. Kassie, M. Household-level determinants of soil and water conservation adoption phases: Evidence from Northwest Ethiopia highlands. Environmental management 2016, 57, 620636. http://dx.doi.10.1007/s00267-015-0635-5

95. Van Ginkel, M.; Sayer, J.; Sinclair, F.; Aw-Hassan, A.; Bossio, D.; Craufurd, P.; El Mourid, M.; Haddad, N.; Hoisington, D.; Johnson, N. An integrated agroecosystem and livelihood systems approach for the poor and vulnerable in dry areas. Food Security 2013, 5(6), 751-767. https://doi.org/10.1007/s12571-013-0305-5

96. Venton, C.C. Understanding community resilience: findings from a community-based resilience analysis (CoBRA) assessments: Marsabit, Turkana and Kajiado counties, Kenya, and Karamoja sub-region, Uganda. In Welteji, D.; Mohammed, K.; Hussein, K. 2017 (ed.) The contribution of the Productive Safety Net Program for food security of the rural households in the case of Bale Zone, Southeast Ethiopia. Agriculture \& Food Security 2014, 6(1), 53.

97. Webb, N.P.; Marshall, N.A.; Stringer, L.C.; Reed, M.S.; Chappell, A.; Herrick, J.E. Land degradation and climate change: Opportunities for building climate resilience in agriculture. Frontiers in Ecology and the Environment 2017,15 (8). pp. 450-459. ISSN 1540-9295. https://doi.org/10.1002/fee.1530

98. Wittwer, R.A.; Dorn, B.; Jossi, W.; Van der Heijden, M.G.A. Cover crops support the ecological intensification of arable cropping systems. Scientific reports, 2017,7,41911. https://doi.org/10.1038/srep41911

99. Wondie, M.; Mekuria, W. Planting of Acacia decurrense and dynamics of land cover change in Fagitalokema district, northwest highland of Ethiopia. Mountain research and development, 2018 38(3), 239-239. http://dx.doi.org/10.1659/mrd-journal-d-16-00082.1

100. Yadeta, B.; Bedemo, A.; Belina, M. Determinants of saving behavior of farm households in rural Ethiopia: the double hurdle approach. Journal of economics and sustainable development, ISSN, 2222-1700(Paper) 2017, 8, 19. www.iiste.org

101.Yin, W.; Fan, Z.; Hu, F.; Yu, A.; Zhao, C.; Chai, Q.; Coulter, J.A. Innovation in alternate mulch with straw and plastic management bolsters yield and water use efficiency in wheat-maize intercropping in arid conditions. Scientific reports 2019, 9, 6364. https://doi.org/10.1038/s41598-019-42790-x

102.Zerihun, M.F. Agroforestry Practices in Livelihood Improvement in the Eastern Cape Province of South Africa. Sustainability 2021, 13, 8477. https://doi.org/10.3390/su13158477 